論文

\title{
都心製造業集積地域の文化的生産 \\ —東京都台東区における「モノづくりのマチづくり」— \\ Cultural Production in the Old Industrial Inner City:
}

A Case Study of 'Mono-Machi' in Taito, Tokyo

下村恭広

Yasuhiro SHIMOMURA

This article seeks to clarify the role of cultural production in the manufacturing industry and its spatial restructuring through the case study of "Mono-Machi" movement: the community development through the manufacturing rejuvenation lead by the local manufacturers in Taito, Tokyo. It is an attempt to form a new business relationship and to put high added value on the local product through the place branding. This article analyses that movement as a socio-spatial transformation of post-industrial urban economy.

\section{1. 文化的生産の空間編成}

都市社会学では都市の社会構造と空間構造との関係に特別な関心を払い、その変化を理 解するためのモデルを提起してきた。そこで論点のひとつとなるのが、どのような産業の 動向を中心に据え、その空間編成を把握するのかということである。たとえばグローバル シティ論は、先進各国の脱工業化と経済のグローバル化が都市の社会一空間構造を変えた 過程を説明する都市モデルである [Sassen, 2001]。ここでは、国境を越えて分散する生産 拠点の中枢管理機能、とりわけ金融業と、事業所向けサービス業の集積に注目する。経済 活動の地理的分散を可能としている中枢管理機能の高度化と複雑化は、専門分化した企業 群の地理的集中が不可欠の存立条件である。この都市モデルは、都心部へのこうした企業 群の集積を強調し、それに伴う社会的経済的不平等の空間的分極化を想定する。グローバ ルシティ論は産業構造の転換と都市空間の関係について明晰な理路を示すが、それだけに 多くの批判的検討の対象となり、そこでは汲み取られない現実を含めたモデルによって相 対化されてきた。そのひとつであるロサンゼルス学派都市論は、脱工業化だけでなく再工 業化も同時進展していることを重視し、フォーディズム的な産業の組織化とは異なる「柔 軟な専門分化」に基づくシティ・リージョンの形成を提示している [Soja, 2000］。これは 都心と郊外との区分が曖昧となるような広範囲なスケールでの都市空間形成であり、その 内部でのモザイク的な空間分化が進展している。こうした都市モデルの違いは、それぞれ 
の学説が念頭に置いている具体的な都市によって焦点を当てる産業が異なり、さらにはそ の空間編成の説明が変わることによる。

以上の二つのモデルで対照的な認識となつているのが、現代都市における製造業の捉え 方である。これは特に、日本の都市の理解において無視できない。というのも日本のとり わけ大都市圈の社会一空間構造では、都市自営業を含む零細規模事業所の厚い集積が見ら れ、それらが比較的近年まで存続してきた点に大きな特徵があるからだ。これは空間構造 の点では、職住一体もしくは職住近接の、住宅と小規模事業所とが混在する地域の形成と して捉えられてきた。具体的には零細小売店が集積する商店街、また町工場が狭い地域で の分業構造を形成して密集する産業地域社会である [板倉・他, 1973]。他方社会構造の点 では、都市自営業は大都市流入層の定着過程の主要ルートのひとつとされ [佐藤, 2004]、 また町内会体制における地域住民組織を構成する主要な担い手と見なされてきた [玉野, 2005]。こうした、社会的上昇移動の機会提供、そして地域自治の基盤という「下町の二 重の役割」は、1970年代以降の脱工業化において英語圈で議論されてきたような「イン ナーシティ問題」が、日本では同様の形で顕在化しにくかった背景として指摘されること もある [園部, 2001]。こうした地域で現在どのような変化が進んでいるのか。またその変 化は現代都市の社会－空間構造においてどのような意味を持っているのか。これは、上記 の都市モデルでは十分に検討されることのない問いである。

そこで、製造業の動向という点からグローバルシティ論を相対化しようとするもうひと つのモデルとして、創造都市論を位置づけたい。創造都市は、大企業中心の大量生産に代 わって、零細企業のネットワークによるクラフト型生産が主軸となつた都市のモデルであ る [佐々木, $2012 ： 44]$ 。そこで言及されるクラフト型生産は、かつての生産システムへの 回帰というより、新しい技術やアートを組み込んだ再構築であり、産業と文化との融合 （文化的生産）が先端的な経済発展の鍵とみなされる。しかし、この学説を都市の社会一 空間構造モデルとするには、文化と産業とが結びつく「創造の場」についての再検討が必 要である。「創造の場」はそこで経済的・文化的価值を創出できるような、芸術、企業、 市民が出会う場であり、信頼関係を基礎にした社会的ネットワークの結び目とされる [佐々木, 2014：231-239］。そうした場は、どのような空間編成に基づいて成り立つのだ ろうか [後藤, 2002］。また、たとえば「下町」のような既存製造業集積の「創造の場」 への発展が可能となるには、いかなる条件が必要だろうか。

「創造の場」の空間論的研究は、「創造的産業」と呼ばれる文化的付加価值の高い財や サービスの生産の立地に関する調査から着手され [後藤, 2006]、主にコンテンツ産業が対 象とされている。それに対して本稿では、既存製造業集積地域の動向との関わりから文化 的生産の空間的編成を考えたい。創造都市の軸としての文化的生産については、ITやメ ディアなどのコンテンツ産業だけでなく、製造業も含めるべきである [水野, $2010 ： 438$ ] デザイン志向が強く文化的価值が付加された製品の製造業は、ファッションが典型的であ 
るがそれにとどまらない。日用品や家電製品でも、機能的側面で差異化しにくくなってい る市場では、文化的・象徵的側面での差異化が不可欠となってきているからだ [河島, $2011 ： 22]$ 。それでは、製造業がこうした文化的・象徽的な差異化を追求する結果、その 空間編成はどのように変わっていくのだろうか。これについては、旧製造業地域における 芸術家街の形成がよく言及される [金, 2012 ; 笹島, 2014]。芸術家が空き家となった倉庫 や工場を改装してスタジオとして使い始め、それがその周囲での画廊、飲食店、小売店の 増加を促し、やがてそうしたリノベーションの手法やそこで培われた審美的基準が開発事 業に組み込まれて富裕層向けの住宅地化へと至る。これは脱工業化によるジェントリフィ ケーションの一環として捉えられることが多い。しかし芸術家街の形成の段階では、資本 の運動による建造環境の生産に還元できない、新しい産業の空間的編成の論理も働いてい る点が重要である [Lloyd, $2010: 47-48]$ 。この観点は日本の都市の文脈では、都心周辺の 細街路に出現した「新しい街」1) に対して続く関心のように、生産の場よりは消費の場と して注目されてきたことだ。とはいえ、こうした細街路の変容を「創造の場」の形成と見 なすことの妥当性は、引き続き吟味されるべきだろう [三田, 2014]。そこでは、文化的生 産がどのような形で既存の都市空間に規定され、同時にそれを活用しているのかという点 の検討が欠かせない。旧製造業地域が諸種の文化的生産者の集まる「文化的街区 (cultural quarter)」へ転換した過程の分析は、経済活動のグローバル化すなわち脱領域化が進む中 での「象徵資源の再領域化」というべき現象に注目している [Bovone, $2005: 377]$ 。製造 業において文化的・象徵的差異化を追求する際、その生産工程が深く依拠している都市空 間は、Zukin [2010=2013] が都市の「オーセンティシティ」として問題にしたような、物 質化した文化的資本となる。その具体的様相は、各都市に固有の文脈を踏まえて明らかに しなければならない。

以上を踏まえた本稿の課題は、製造業における文化的生産の進展と、それが従来とは質 的に異なる空間編成を伴う過程を、東京の製造業集積地域において示すことだ。大都市製 造業集積地における自治体産業政策では、生産拠点の海外移転が進む中で、既存の産業集 積を単に消えゆく存在として見るのではなく、縮小しつつもそこに新たな機能が形成され る契機を見いだそうとしてきた [植田, 2004]。そこには様々な取り組みがあるが、ここで 注目すべきは製造業を観光資源と結びつける試みだ。ファッション雑貨工業の集積地であ る墨田区は、1980年代から「工房文化の都市」を目指し、小さな博物館、すみだマイス ター、工房ショップから成る $3 \mathrm{M}$ 運動を展開し、この分野における先駆的事例とされてい る [黒瀬, 2006:295-300]。近年では新たな形態での工場見学のイベント(オープンファ クトリー）を実施して製造業事業者と消費者との接点を広げようとしている。同様の動き は、機械金属工業の集積地である大田区で展開されている「大田クリエイティブタウン構 想」にも見られる [岡村・他, 2014]。ここでは町工場の減少が続く中、新たな創造産業の 育成を、産業政策の枠内にとどめず、工場一斉公開イベントのような生産過程の観光資源 
化や、新たな産業の担い手を呼び込めるような空き工場の創造的活用といつた事業と結び つけている。これらはいずれも、地域のオーセンティシティを確立することによる、製造 業における文化的価值の産出の試みにほかならない。それらは関与主体にとっていかなる 必然性をもって展開しているのだろうか。

これについて本稿では、台東区南部の「徒蔵 (かちくら)」一御徒町一蔵前間——事 例に基づき明らかにする。台東区も墨田区や大田区と同様の動きが、民間事業者の主導に より進んでいる ${ }^{2)}$ 。複数の製造業事業所が連携して進めている「モノづくりのマチづく り」である。その取り組みは、台東区のインキュベータ（創業支援施設）である台東デザ イナーズビレッジが開設されて以来、そこを卒業した企業の地域定着を契機として始まっ $た^{3)}$ 。この事例の特徵は、製造業事業所が「徒蔵」と呼ばれる新しい空間を生み出そうと している点である。この空間はごのようなもので、その出現は何を意味するのか。本稿で はこれを隅田川流域のファッション雑貨工業集積の空間編成に起きている変容として捉 え、その意味を理解できる最も顕著な局面として、事業者が従来の生産システムからの脱 却を強いられるなか、既存の社会的分業構造とは異なる取引関係を作り出そうとする試み に焦点を当てる ${ }^{4)}$ 。

\section{2. ファッション雑貨工業の社会的分業構造と空間編成}

\section{1 ファッション雑貨工業の社会的分業構造}

東京の隅田川流域は、ファッション雑貨工業 (ハンドバッグ、鞄、靴、ベルト、革小物 類、ジュエリー、アクセサリー等の製造業）の集積地域である。ファッション雑貨工業は 零細事業所が中心で、問屋を中心に、メーカー、加工業者 (下職、職人) が生産工程を分 業して生産活動を展開している。製品によって様々な業界に分かれるが、中でも袋物製造

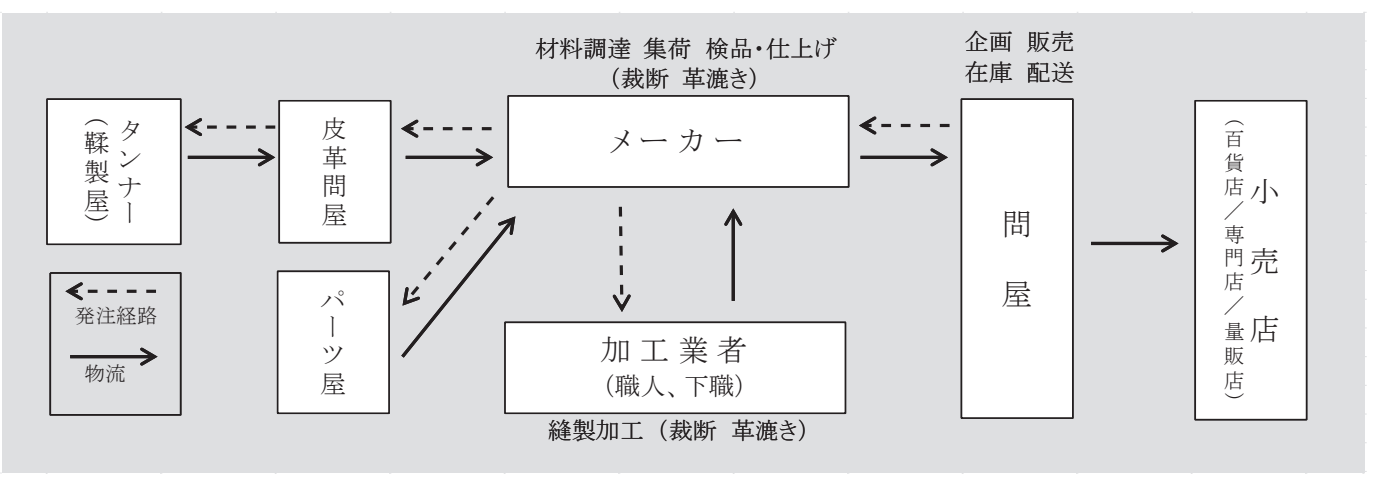

図 1 袋物製造業の生産流通機構

台東区中小企業実態調査協議会 [1987] および聞き取り調査に基づき作成 
業5) の有する特質は、東京のファッション雑貨工業の調査研究においてその典型と見なさ れてきた。袋物の生産流通機構は、問屋、メーカー、加工業者、関連業者によって取り結 ばれている社会的分業構造によって成り立つ。この構造は 1970 年代後半から 80 年代にか けて集中的に調査研究の対象となり [板倉・他, $1970 ； 1973$; 佐藤, 1981 ; 台東区中小企 業実態調査協議会, 1987]、近年の研究でもその基本形態の存続が確認されている [遠藤, 2007]。

問屋は、製品を企画・デザインし、試作品を作りながらメーカーと相談して生産計画を 立て、メーカーに生産を発注し、納品された製品を小売店に卸す。問屋は百貨店、専門 店、量販店等、卸す先によって専門分化しており、近年はネット販売に強い会社などもあ る。メーカーは問屋から受注した製品について複数の加工業者に製造させ、それを取りま とめて問屋に納品する。製造にあたつて必要な資材、例えば革、裏地、ファスナー、金具 類、ベルト等はそれぞれの専門業者から取り寄せ、それを加工業者に渡すのもメーカーの 役割である。革の裁断と革漉きの工程については自社工場で行う場合と、専門の加工業者 に発注する場合とがある。問屋は数社から十数社のメーカーと取引している。メーカーは 得意とする素材 (革、繊維、ナイロン等) や用途 (フォーマルかカジュアルか)、生産能力 の多寊などによって分化している。加工業者は実際の製造工程に携わる事業所で、「職人」 や「下職」と呼ばれる。加工業者は製造工程によって分担して作業するのが基本である。 加工業者が工程の一部を「内職」に発注する場合もある。もともとその多くは夫婦で経営 しているような小さな会社で、現在は高齢化が進んでおり、確保が難しい状況である。そ のため近年は海外の加工業者に発注する業者も珍しくない。

\section{2 都市空間形成過程の中のファッション雑貨工業}

袋物製造業は煙管入れ、がま口、巾着、胴乱等の製造から始まっており、明治時代まで は日本橋周辺の大通りに面して店を構える問屋と、その裏店に居住し加工を行う下職とに よって構成されていた [板倉・他, 1970：88］。1920年代にこれらの事業所がハンドバッグ 製造に発展していく過程で下職層が分化し、傘下に複数の下職を取りまとめる有力な下職 が現れ、これがメーカーとなっていった。こうした中間業者の形成は、高度経済成長期に おける業界の拡大期においても同様であった。また、このような形で社会的分業構造が確 立していった過程は、他のファッション雑貨工業でもみられる [中山, 1983：212]。

ファッション雑貨工業における以上のような社会的分業構造の確立過程は、隅田川流域 の住工混在地域の形成過程でもあった。この住工混在地域は、各業界における問屋の集中 する地域、メーカーの集中する地域、加工業者の多い地域という三層が、浅草橋と日本橋 横山町を要に扇状に地帯分化している (図 2)。この空間構造は、加工業者が地代の安い外 縁部で独立開業することによって拡大し、またそうして独立した加工業者の中から中間業 者が現れてくることによって分化してきた結果である。19世紀までの加工業者地帯は東の 


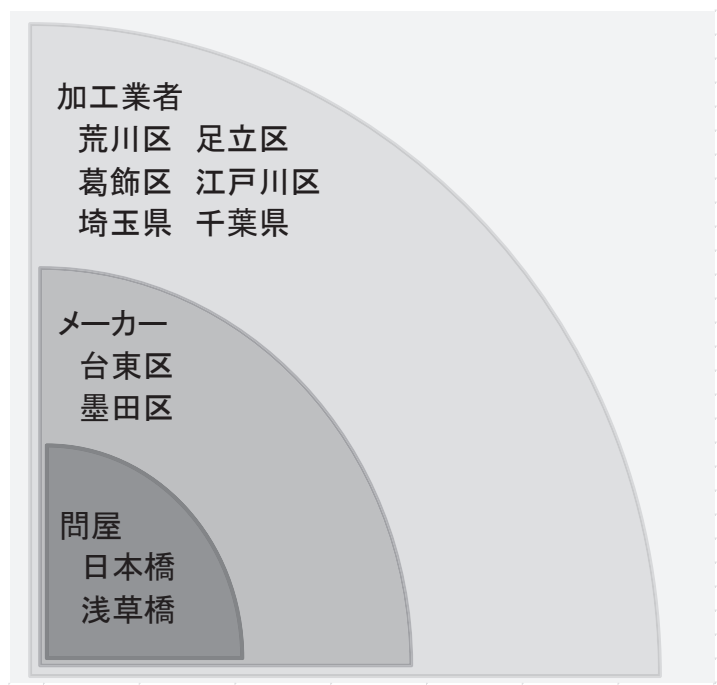

図 2 袋物製造業の立地における地帯分化 板倉・他 [1973］に基づき作成

本所から北の日暮里あたりまでを外縁としていたが、それが関東大震災を契機に東辺の亀 戸から四ツ木、千住を経て北辺の三河島あたりまで拡大し、さらに高度経済成長期には江 戸川区、葛飾区、足立区に拡がった [板倉・他, 1973：92]。この限界は、地代の安さと メーカーや問屋との時間距離との兼ね合いで決まる。各業界の加工業者の間では「橋を 渡ってはいけない」と言い伝えられてきたというが、そこでいう橋のかかる川は、隅田川 だった時代から、荒川放水路、そして江戸川へと変わってきたのである [板倉・他, $1973: 72]$ 。

台東区徒蔵——東の地下鉄蔵前駅から西のJR御徒町駅までの地域——は、問屋の集積 地域に隣接したメーカーの集積地域である。一帯は関東大震災後の復興区画整理事業が実 施された地域であり、碁盤の目状に街区が構成されている。幹線道路で囲まれた大街区の 外周部は高層化しているが、それに囲まれた内側は中・低層の住商・住工併用の建物が並 ぶ。印刷業のほか、袋物、包装資材、紙器のメーカーが目立ち、それらに交じって革漉き や箔押といつた革製品の中間加工を担う事業者の小さな作業場も点在する。かつてはさら に、洋傘や帽子を製造する工場が多かった [井出, 1973]。御徒町と蔵前の中間地点一帯は 戦災を免れたため、銅版張りやモルタル塗りの近代町屋群や路地が残つているが、比較的 広くまとまった敷地にはマンションが建ち始めている。

\section{3 ハンドバッグ市場の現状に見るファッション雑貨工業の苦境}

ファッション雑貨工業の空間的編成は 1980 年代前半までに形成されたものだが、 90 年 代以降は事業所数が減少し、集積地が空洞化しつつある。それがごのような過程なのか、 
ハンドバッグにおける近年の市況を例にまとめておこう ${ }^{6)}$ 。現在ハンドバッグ市場は高価 格帯と低価格帯へ分極化しており、それぞれ欧米からの輸入とアジア諸国からの輸入が増 大している。これまで東京のハンドバッグ生産者は、中間価格帯を中心に百貨店で販売さ れる製品を手がけてきた。中でも 1970 年代以降大きく成長できたのは、海外有名ブラン ドの国内ライセンス生産を担っていたからである。たとえばバーバリーの製品の場合、洋 服を三陽商会が生産していたのと同様に、革小物類についても台東区内の問屋及びその問 屋と系列取引のあるメーカー、加工業者が生産してきた。これによってイギリスからの輸 入品よりは安いが、高品質の商品として百貨店を中心に販売されてきたのである。しか し、近年は海外ブランド各社がブランドの希少性をいつそう高めるために、こうしたライ センス契約を打ち切るようになっている。また、そもそも百貨店の売上の減少が長期的に 続いている。これにより地域と百貨店および海外ブランドとをつないできた問屋が地域か ら離れ、低価格の製品を大量に生産できる近隣諸国の工場との取引に軸足を移すことにな りつつある。その結果、これまで問屋と系列取引をしてきたメーカーと加工業者は、独自 に商品を企画し、販売することができる製造小売への転換を試みるようになつている。い わば、生産・流通の仕組みやそれが基づいていた役割分担が変わり、各事業者は新しい業 態への転換を強いられている。とはいえ、従来は問屋が中心に商品企画とデザインを行っ てきたこともあり、メーカーや加工業者がすぐに単独で、従来以上に付加価值の高い商品 を製造することは難しい状況である。

\section{3. 社会的分業構造の再編と新しい空間の創出}

\section{1 台東デザイナーズビレッジとクリエイター}

以上の点を踏まえてここからは、台東デザイナーズビレッジ（以下、デザビレと略す） の開設とそこを卒業した企業の地域定着、および地元企業との関係形成に注目し、その過 程にこの地域における新しい空間の創出が表れていることを明らかにしたい。ここでの記 述は、この事業について政策目標に照らして検証するというより、このような事業が引き 起こした出来事の中から、この地域の変化を理解できる局面を明らかにする作業である。

デザビレは、旧台東区立小島小学校として 1920 年代に建造された校舎内にある。児童 数の減少に伴う小学校の統廃合により学校の跡地利用が模索され、その際に経済産業省と 東京都の新事業支援施設整備費補助金を利用して改装された。運営主体はコンぺにより選 ばれ、経営コンサルタントの株式会社ソーシャルデザイン研究所（代表鈴木淳氏）が受託 し、常駐のインキュベーションマネージャーとして現在に至つている。デザビレの構想 は、台東区の依頼を受けてファッション産業人材育成機構が提案した「(仮称) 台東デザ イナーズビレッジ構想」に基づく [台東区産業部経営支援課，2004]。その最大の特徴は、 区内の産業にデザインを提供できるデザイナーを集積するというものだつた。これは、す 
でに述べたハンドバッグ製造業での現実を受けてのことである。今後さらに海外で製造さ れた安価な製品との競争が進むことで区内の下請け製造業の存続が難しくなるため、デザ イン志向の高付加価值製造業への構造転換が必要であるという現状認識に基づいていた [台東区産業部経営支援課, $2004: 80$ ]。そこでデザイナーの新規開業者の創業と定着を促 し、メーカーや加工業者が彼らデザイナーと付加価值の高い製品を製造していくことが目 指された。

ここで重要な点は、入居企業の募集の結果、当初想定していたようなデザイナーが集ま らなかったことである。入居企業は問屋やメーカーにデザインを売るというよりも、自ら 手を動かして創作することへの志向が強い人々が多かった。彼らはデザイナーと区別され て「クリエイター」と呼ばれる[鈴木, 2011]。クリエイターでは、当初想定されていたよ うな形で地元企業の需要を満たすことはできない。なぜなら年間 100 200の試作品の型 おこしをする企業内デザイナーと異なり、創業したてのクリエイターの場合、年間 10 型 くらいしかデザインできないので、経験がそしいからである7)。彼らは特に、量産を前提 とした製品をデザインした経験が少ない。つまり、デザビレで地元企業にデザインを提供 するということは、少なくとも短期的には実現できる見込みがないことが明らかとなつた のである。

\section{2 社会的分業構造の変容とクリエイターの地域定着}

当初の政策意図で想定されていなかつたクリエイターがやがて地域に定着していった過 程は、この地域における社会的分業構造の変化をうかがわせる。零細企業の創業過程は、 もつぱら創業者の力によって進むというより、彼らを取り巻く多数の取引先やそれらが依 拠する産業地域社会との関係を通じて実現していくものである [渡辺，1997］。このように 創業を多数の関与主体の相互作用とみなす観点に立って、以下ではクリエイターの創業= 地域定着過程について述べる。

デザビレ開設から 10 年を過ぎた現時点において、卒業企業は 56 社であり、そのうち台 東区内で開業した企業は累計で 24 社である ${ }^{8)}$ 。卒業企業の事業内容をその取扱品目で分け ると表 1 の通りである。装身具／宝飾品、雑貨・文具、革小物・バッグといつたように、 台東区内に同業種集積が見られる品目において、区内で開業した企業が多い。また、現時 点では多くの企業は従業員 5 人に満たない零細事業所である。卒業企業の代表者のうち 7 割が女性である $(56 \text { 社中 } 39 \text { 社 })^{8)}$ 。2014 年現在の入居企業代表者でも、女性は約 8 割を占 める。入居時点では 20 代後半から 30 代が多く、現在の入居企業代表者で最年少が 24 歳、 最年長が 45 歳、平均年齢は 31 歳である ${ }^{9)}$ 。ほとんどの代表者は台東区外の出身者である。 また、学歴では大学・大学院卒が最も多く、美術大学の出身者が多い。

デザビレに入居したクリエイターの企業としての成長は、「手作り作家」から「メー カー」への移行とでも呼ぶべき過程を経る [鈴木, $2011: 116-9]$ 。つまり、一方で展示会 
表 1 卒業企業の事業内容

\begin{tabular}{|c|c|c|}
\hline 業内容（取扱品目による区分） & 卒業企業 & 台東区で開業した企業 \\
\hline 装身具／宝飾品 & 14 & 9 \\
\hline アパレル & 12 & 2 \\
\hline 雑貨・文具 & 9 & 5 \\
\hline 革小物／バッグ & 6 & 5 \\
\hline 靴 & 4 & 1 \\
\hline 写真 & 2 & 0 \\
\hline 手芸 & 2 & 1 \\
\hline 伝統工芸 & 2 & 1 \\
\hline $\begin{array}{l}\text { その他（フィギュア、テキスタイル、 } \\
\text { 帽子、家具、ウェブ） }\end{array}$ & 5 & 0 \\
\hline 合計 & 56 & 24 \\
\hline
\end{tabular}

台東デザイナーズビレッジのホームページ掲載情報及び各企業のホームページ掲載情報に 基づき作成

に出展を続けて小売店のバイヤーから注文を取りつつ、趣味の延長のような手作りではな く、近隣地域の加工業者に生産を発注し、量産体制を整えることである。いわば企業とし ての自立は、地域での社会的分業構造の中に入り込むことで実現される。この意味での自 立は、連続したステップを一歩ずつ上がっていくように成し遂げられるものではない。新 規開業者の視点に立つと、途中に大きな障壁のようなものがある不連続な道のりとして経 験される。その障壁を、ここで生産ロット、取引慣行、技術・製品の評価基準の三点に分 けておこう。

もつともよく聞かれるのが、生産ロット（受発注の単位）をめぐる障壁である [鈴木, 2006]。デザビレのインキュベーションマネージャーは次のような例を挙げる。「縫製工場 は三十着からしか受けてくれない。自分はもう十着縫うと手一杯でもう他の仕事はできな くなる。その間をどうやって埋めていくかというのが、その手作り作家からメーカーに移 る一番難しいところで」 ${ }^{7}$ 。現在オリジナルテキスタイルと財布を製造しているクリエイ ターの場合、デザビレ入居前は商品の 8 割を手作りしていた ${ }^{9)}$ 。そのため入居当初、小売 店からの注文が増えていくにもかかわらず、生産が間に合わないといつた事態になつた。 そこで生産工程の一部を発注できる加工業者を周辺地域で探し、自分の作業を 2 割まで減 らすことにした。しかしこのように外注する体制を取れたとしても、手持ち資金が少ない と、工場に生産を発注したくても、小さいロットでの発注しかできない。この場合、少量 生産したものを何とか売って次の発注のための資金をようやく工面する、という自転車操 業となる。

このように大きなロットでの取引ができないクリエイターは、それゆえに業界における 
暗黙の取引慣行に従うことができない場合が出てくる。例えばハンドバッグの場合、製造 に必要な材料は問屋を通す規範がある。しかし、そのためには大きなロットでの購入が求 められる。しかも、問屋を通すと色や触感の選択肢が狭い。ハンドバッグや革小物を扱う あるクリエイターはオリジナルな革にこだわるがゆえに、直接タンナーから革を仕入れる こととなった。これは本来許されないが、現在は取扱商品の絶対量が少ないので大目に見 てもらっている状況だという。

以上の過程は、既存の事業者からはどのように捉えられているのだろうか。とりわけ加 工業者から見ると、クリエイターは製品の仕上がりのイメージを共有しにくいためコミュ 二ケーションが難しい。この仕上がりのイメージの違いは例えば、技術に対する評価の違 いに現れる。「これはデザビレ出身者に多いパターンだけど、箔押しを名入れとしてでは なく、模様として使うことが多いよね。だから、セオリーが通用しない。例えばビニール コーティングにスエードの生地を組み合わせている製品があるでしょう。素材ごとに適し

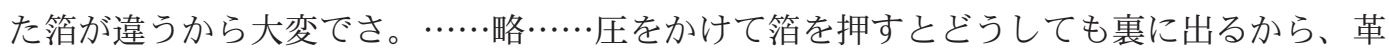
の専門家だったら裏地と表地を別々に作って貼り合わせるところだけど…… [台東モノ マチ編集部, $2014: 4]$ 。このような技術の適用の仕方は、金銭的・時間的費用を踏まえて 選択される。多くの場合その選択基準は、業界内での長年の取引関係における定型化した 工程を前提につくられている。加工業者にとってクリエイターとのコミュニケーション は、このような技術体系をいつたん白紙にして調整するかのように受け止められる。その ため、そもそもクリエイターを一人前の取引相手とは思えない業者もいる [有限会社浅原 皮漉所, 2013]。

こうした障壁を超えることができるのは、クリエイターと既存業者との間に仲介役を果 たす人々がいるからである。まず思い起こされるのはインキュベーションマネージャーで あり、次いで他の入居者や先輩の入居者による紹介である。しかしいずれも、既存業者の 側でクリエイターとの取引に対して何らかの期待がなければ、仲介は成り立たない。彼ら にとって新規開業者との取引は手間がかかることであるが、どのようなメリットを見出し ているのだろうか。そこには既存の社会的分業構造とは異なる取引関係を作り出そうとし ている動きの一端を見ることができる。これを、袋物製造業における加工業者のひとつで ある箔押業を営む業者の事例に基づいて述べたい ${ }^{10)}$ 。箔押とは印刷技術のひとつである。 例えば布や革で装丁された書籍には題字が立体的に印刷され、その文字に金箔が熱転写さ れている。同様に鞄や財布などの革製品でも、ブランドロゴなどがやはり立体的に押され ていたりする。製品の形状や素材によって箔の押し方が異なるため、専門の業者によって 担われる。近年はこの工程も、大きなロットで定型的な仕事は海外へ移転され、国内の業 者へはもつぱら短期納品で小さなロットを発注する傾向が強まっている。いわば、大量生 産から多品種少量生産への転換が強いられているのだが、こうした短期で小ロットかつ初 めてに近い素材や形状での仕事は、準備に手間を取られる割には対価を得にくい。 
デザビレ近隣にある複数の管押所の中の一社は積極的にクリエイターとの取引を続けて おり、デザビレ卒業企業のうち、約半数と取引経験がある。そうした加工業者の立場から は、クリエイターとの取引に期待することは第一に、消費者のニーズについて想像する手 がかりが得られることだ。これはある種の新鮮さを伴って体験されているが、それは長期 にわたつて特定の業者と取引を重ねてきたため、加工の仕事もその関係の中でいかに効率 よく進めていくかという基準にもつぱら基づいて認識し、評価するようになっているから である。第二には、彼らとの仕事が、従来とは異なる社会的分業のあり方を予感させるか らだ。この業者は既存の社会的分業の中での働き方を、「殼にこもつた町工場」と表現す る。それと比較するとクリエイターとの仕事は、それ自体から得られる経済的利益はわず かであるが、今までとは異なるつながりの中で自分の仕事が活かされる可能性への期待と して経験される。「彼らってのはネットワークがね、全然職人と違ってあるんですよ、す ごく。‥横のつながりとか、そういうもの? …だからそういう人たちと付き合ってると、 おのずと自分も今までなかつたそういう付き合いとか、モノを発信する力が付いてくるつ ていうか。だからそっちの方が重要で、誰かとコラボして一発当ててやるっていうのでは なくて、少しずつ、殼にこもつた町工場じゃなくなっていくというところが、彼らと一緒 にいる、一番のところ」年。加工業者のように他社との分業を前提に特定の工程に特化し た事業者の場合、誰とどのような取引関係を結びながら仕事をこなすのかが重要である。 従来はこれが問屋を中心とした取引関係によってほぼ固定化されていた。技術に対する評 価や商品の製造で実現すべき目標も、その中で与えられるものであった。社会的分業構造 の変化は、これまで消費者と直接接することのなかった加工業者が消費者と直接つながる 経路を模索し、これまでは求められなかった技術の活かし方を生み出そうとする中で進ん でいるのである。

\section{3 モノマチと徒蔵の創出}

以上のように取引関係の模索を進める事業者は、都市空間に対しても自らの事業の新し い基盤と捉え、新たな働きかけをしつつある。これをよく示しているのが、徒蔵にある 様々な業種の事業所が参加する「モノマチ」(モノづくりのマチづくり）と呼ばれる地域イ ベントである。

モノマチは 2011 年に東京スカイツリー開業に合わせて企画され、現在はメーカーを中 心に 100 社以上が参加して開かれるようになっている（表 2)。その母体となったのはデザ ビレが年に一度行っていた施設公開イベントである。このイベントは、卒業企業が近隣地 域に自らの商品を販売する店舗兼アトリエを開くようになって以降、こうした卒業生と、 彼らとつながりのある既存の事業者 16 社を巻き込んで開催する形態へ発展した。第 1 回 のモノマチは予想以上に来客者数（のべ 1 万人）を集め、参加企業は短期間で増加した。 既存の事業者の参加者は当初ほとんど相互に面識がなく、会社が隣接していてもイベント 
表 2 モノマチ開始当初の各回における参加事業所数の移り変わり

\begin{tabular}{|c|c|c|c|c|}
\hline & 第1回 & 第2回 & 第3回 & 第4回 \\
\hline & $\begin{array}{c}2011 \text { (平成 } 23 \text { ) 年 } \\
5 \text { 月 } 20 \text { 日 }-21 \text { 日 }\end{array}$ & $\begin{array}{l}2011 \text { (平成 } 23 \text { ) 年 } \\
11 \text { 月 } 18 \text { 日 } 19 \text { 日 }\end{array}$ & $\begin{array}{c}2012 \text { (平成 } 24 \text { ) 年 } \\
5 \text { 月 } 25 \text { 日 }-27 \text { 日 }\end{array}$ & $\begin{array}{c}2013 \text { (平成 } 25) \text { 年 } \\
5 \text { 月 } 24 \text { 日 }-26 \text { 日 }\end{array}$ \\
\hline 参加事業所合計 & 113 & 208 & 243 & 399 \\
\hline 企業／店舗／職人 & 16 & 62 & 119 & 199 \\
\hline クリエイター(デザビレ) & 34 & 50 & 37 & 30 \\
\hline クリエイター (モノづくり市) & 53 & 64 & 60 & 98 \\
\hline 飲食店 & 10 & 32 & 26 & 54 \\
\hline おかず横丁 & 0 & 0 & 0 & 15 \\
\hline 高校 & 0 & 0 & 1 & 3 \\
\hline
\end{tabular}

台東モノづくりのマチづくり協会資料に基づいて作成

の開催を通じて初めて面識を得たという例もあった。実施主体はその後、デザビレから実 行委員会へと移行した。実行委員会はメーカーの経営者と加工業者を中心とする地元製造 業事業所、そしてデザビレを卒業したクリエイターで構成されている。

モノマチは三つの要素で構成されている。第一に、母体となったデザビレの施設公開で ある。これは普段は見学できない施設の一般公開で、入居クリエイターが自室のアトリエ で商品を展示販売する。第二に、クリエイターズマーケットである。これは地域外の「手 づくり作家」(アマチュアからセミプロレベルの工芸作家)による作品の展示販売会であ る。そして第三に、地域の製造業事業者が主体となる企画である。これは普段は小売りを しない問屋、メーカー、職人などによる工房見学、ワークショップ、販売、ならびにこれ らの各地点をつなぐ案内付ツアーである。

モノマチの最大の特徵は、工場などの製造現場を一般に公開し、また期間限定の小売も 行い、来場者がそれらを見ながら域内を回遊する点にある。たとえば革製の名刺入れを、 来場者がある場所で材料を購入し、そのあと裁断、皮漉き、䇴押、縫製についてそれぞれ の工場を歩いて回りながらひとつの商品を仕上げていくうちに、この地域での製造工程を 目にすることができるという、体験型の企画が実施されている。これは、実際に生産して いる人々や彼らが働き暮らしている場所を知ってもらうことで、その製品に他にはない価 值を与えることを意図している。これによって、徒歩で回遊できる範囲がイベントの開催 地域の「徒蔵」として明確に確定されたと同時に、その範囲内で様々な事業者が連携する 企画が練られるようになった。

「徒蔵」という名称は、デザビレが 2010 年に都心の小売店と提携して入居クリエイター の展示販売を開催した際に、雑誌での宣伝向けに創出された ${ }^{7)}$ 。そのため古くからある地 名でもなければ、連合町内会や学区のような行政区画にも対応していない。このような名 
称がモノマチと結びついて新しい空間の創出に至つた過程は、三つの異なる側面をあわせ 持っている。第一にそれが、消費者に対するアピールの手段として持つ意味である。 ファッション雑貨工業が直面する苦境として述べたとおり、生産拠点のグローバル化が進 む中で従来の産地のメーカーや加工業者が製造小売業としての存続を図り、付加価值の高 い独自商品を製造するには、自力で販路を開拓し、商品の認知度を上げなければならな い。これは比較的規模の大きなメーカーであれば企業単体で挑戦できるにしても、小規模 事業所では難しい。これまでこの地域は、有名ブランドのライセンス生産を行ってきた結 果、そのブランドを前面に立てるために、実際に製造がなされる場所についての情報を発 信することはなかつた。むしろ、どの商品がごこで誰によって作られているのかについて 公言することは避けられてすらいたという7)。そのため、南に秋葉原や浅草橋、北に上野 や浅草といつた繁華街に隣接していながら一般的には知名度の低い区域であったし、製造 業事業者もまたそれを問題視しなかったのである。モノマチが行っているのは、従来の社 会的分業構造が転換する中で、「徒蔵」という名称によって従来なかった空間的単位を創 出し、一般消費者に対する地域の認知度を高めようという試みだといえる。

第二にそれが、街を歩くという実践なしには範域が確定されなかったことが重要であ る。この地域は一般消費者向けの店舗がある地域ではなかつた。それを踏まえると、クリ エイターが店舗を併設したアトリエをこの地域に開いたのは、重要な転換点であった。既 存の製造業事業者がこの地域で小売りの店舗を出すことを想像もしなかつたなかで、クリ エイターは老朽化した建物に手を加えてアトリエ併設店舗に改装した ${ }^{11)}$ 。クリエイターに とっては、徒蔵が認知され訪れる人々が増えることや、そうした人々が回遊できるような 店舗群が生れることは、店舗経営にとつて重要な意味をもつ。また既存のメーカーや加工 業者にとつては、消費者と接触する機会の増加でもある。従来は彼らと一般消費者との間 には問屋と小売店が介在しており、彼らが自分の製品の使用者に直接会うことはなかつ た。この地域は、メーカー・加工業者が消費者の嗜好や興味の所在を知るための場となつ ている。

第三にこの空間の創出が、イベントを通じた域内事業所間の関係構築を伴って進んだこ とである。モノマチには表 3 に挙げたような様々な業種の事業所が参加しているが、この 地域ではもともと同業者以外での面識は希薄であった。製品ごとに問屋を頂点として系列 化された取引関係によって生産されていたため、自分とは異なる製品を作る業者、また同 業種でも別の問屋と取引している業者と知り合うことはなかつた。モノマチに参加してい る企業は他業種かつ多業態にわたるが、彼らがイベントの企画を練り、運営していく過程 を通じて互いの事業内容について知ることができ、それによってこれまではなかった取引 関係が生まれている。この意味で「モノづくりのマチづくり」とは、「モノづくりのマチ」 のアピールだけではなく、これまでとは異なる「モノづくりのマチ」を作ることでもあ る。 
表 3 第 3 回モノマチ参加企業「企業/店舗／職人」のうち、 $2 k 540$ 入居企業を除く 74 社の取扱品目別の事業所数

\begin{tabular}{|l|c|}
\hline バッグ・財布・革小物 & 22 \\
\hline 文具・雑貨 & 14 \\
\hline ジュエリー/アクセサリー & 6 \\
\hline 伝統工芸 & 5 \\
\hline デザイン事務所 & 4 \\
\hline ケース/包装 & 4 \\
\hline 食器 & 3 \\
\hline 建築 & 2 \\
\hline アパレル & 2 \\
\hline 印刷 & 2 \\
\hline その他 & 10 \\
\hline 合計 & 74 \\
\hline
\end{tabular}

第 3 回モノマチパンフレットに基づいて作成

\section{4. まとめ}

都市社会学が社会構造と空間構造を関連付けようとするのは、それによって初めて理解 できる現実があるからにほかならない。創造都市論において産業と文化の接点に関する問 題提起をなしうるのも、両者を都市空間との関わりで捉えようとしているからである。本 稿はこの観点に立ち、大都市製造業集積地における産業と文化との関係を、そこで新しい 空間が創出される過程から把握することを試みた。

製造業において文化的・象徵的な差異化が追求されることは、大都市製造業集積地にお けるその空間編成のありようをどのように変えるのか。本稿はこれを、台東区南部におけ る徒蔵という新しい空間の創出を事例に説明した。新しい空間の創出は、生産拠点のグ ローバル化によって産地の社会的分業構造が変容し、小規模の製造業事業者がより付加価 值の高い商品の生産を求めることと、またそうした事業者と取引をしながら地域に定着し て新規開業するクリエイターが出現することと結びついた過程である。この地域に集積す る様々な業種の製造業事業所は、従来の問屋を中心とした社会的分業ではありえなかつた ような形で、地理的近接性に基づく関係を作ろうとしている。彼らが関与している空間形 成過程は、消費者にアピールする地域のブランド化、消費者の回遊する経路を作り出し消 費者との接点を広げようとする営み、これまでの分業とは異なる形で域内における取引関 係を作ろうとする試み、という三つの側面を併せ持つものであつた。 
注

1）「新しい街」とは、繁華街に隣接しながら、敷地が狭く建造物が老朽化して家賃の割安な細 街路において、建造物にリノベーションを施した個性的な店舗が開業し、賑わいを生み出す現 象である [大阪府立産業開発研究所, 2003]。

2）また台東区役所は、近年の区内での各業界の取り組夕を踏まえ、産業振興策が目指すべき方 向として「創造力あふれる産業文化都市」を掲げている [台東区文化産業観光部にぎわい計画 課, $2012: 29]$ 。

3）許 [2013] ではモノマチの背景として、地域に集積するファッション雑貨工業の状況に加え て、この地域の南部の東日本橋－神田地域で 2000 年代に高まったリノベーションの影響を示 唆している。

4）本稿のための調査は、2013年度に玉川大学リベラルアーツ学部の社会調査実習の指導を兼 ねて実施された。そこではモノマチ、台東デザイナーズビレジ、対象地域、ハンドバッグ製造 業を中心とするファッション雑貨工業に関する文献資料や官庁統計を収集し、また当該地域の イベント（第 4 回モノマチ、第 2 回A-round）へボランティアスタッフとして参加、その準備 過程における観察とインフォーマルな聞き取りを行った。そのうえでモノマチに関与している 人々について、地域産業の社会的分業構造において占める位置に注意しながら対象を選び、聞 き取り調査を実施した。問屋 2 名、メーカー 4 名、加工業者 2 名、新規開業者 5 名、台東区役 所産業観光振興課、台東デザイナーズビレッジインキュベーションマネージャー 鈴木淳氏か ら協力を得られた。調査で得られた知見については、第 2 回A-round (2013 年11月16日) にあ わせて調査実習報告会を開催し、調査協力者への意見を仰いだ。

5）袋物製造業は、日本標準産業分類の小分類におけるカテゴリーで、ハンドバッグと革小物 （財布や名刺入れ等）を製造する事業所を指す。鞄製造とは技術体系、業界団体が異なる。

6）以下の記述はハンドバッグ問屋 C氏へのインタビュー（2013年 2 月 13 日）ならびに金融財政 事情研究会 [2012] に基づく。

7）台東デザイナーズビレッジ 鈴木淳氏へのインタビュー（2013 年 3 月 22 日）に基づく。

8）台東デザイナーズビレッジ及び各企業のホームページ掲載情報に基づく。

9）台東デザイナーズビレッジ入居企業卒業報告会（2014年 4 月 25 日）での報告に基づく。

10）加工業者 $\mathrm{N} 氏$ のインタビュー（2014年 7 月 1 日）に基づく。

11）メーカー経営者 $\mathrm{K} 氏$ ・ L氏へのインタビュー（2014年 4 月 17 日）に基づく。

\section{文献}

Bovone, Laura, 2005, "Fashionable Quarters in the Postindustrial City: The Ticinese of Milan," City \& Community 4(4), 359-380.

遠藤貴美子，2012，「東京城東地域におけるカバン・ハンドバッグ産業集積の存続基盤——企業 間の受発注連関とコミュニケーションの分析を通じて」『地理学評論』85(4)：342-361.

後藤和子, 2002,「創造的都市論への理論的アプローチ—文化政策学、文化経済学、経済地理 学の視点から、場と関係性の概念を中心として」『文化経済学』3 [4] : 1-17.

後藤和子，2006，「創造性の三つのレベルと都市——欧州の動向を踏まえて」端信行・中牧弘 允・NIRA編『都市空間を創造する一一越境時代の文化都市論』日本経済評論社. 井出策夫, 1973, 「大都市零細産業集団地域の内部構造」『地理学評論』46 (10)：668-674. 板倉勝高・井出策夫 - 竹内淳彦, 1970, 『東京の地場産業』大明堂. 
板倉勝高・井出策夫・竹内淳彦, 1973, 『大都市零細工業の構造——地域的産業集団の理論』新 評論.

河島伸子，2011，「都市文化政策における創造産業——発展の系譜と今後の課題」『経済地理学年 報』57:295-306.

金 善美, 2012,「現代アートプロジェクトと東京『下町』のコミュニティ—ジェントリフィ ケーションか、地域文化の多元化か」『日本都市社会学年報』30：43-58.

金融財政事情研究会編, 2012, 『業種別審査事典第 2 巻 紡績・繊維・皮革・生活用品』（第12 次）金融財政事情研究会

許 伸江, 2013, 「東トーキョーエリアの地域活性化の現状と課題—ものづくりとまちづくり をつなぐ「徒蔵（カチクラ）」地域の取り組み」『跡見学園女子大学マネジメント学部紀 要』 $15: 177-196$.

黒瀬直宏, 2006, 『中小企業政策』日本経済評論社.

Lloyd, Richard, 2010, Neo-Bohemia: Art and Commerce in the Postindustrial City, $2^{\text {nd }}$ edn. New York: Routledge.

三田知実，2014，「大阪市中央区南船場における問屋街からファッショナブルな都市細街路への 変容過程」『応用社会学研究』56:123-140.

水野真彦，2010,「2000年代における大都市再編の経済地理一一金融資本主義、グローバルシ ティ、クリエイティブクラス」『人文地理』62(5) : 26-43.

中山金治, 1982, 『中小企業近代化の理論と政策』千倉書房

岡村 祐・野原 卓・川原 晋・大田クリエイティブタウン研究会, 2014, 「大田クリエイティ ブタウン構想と実践」『季刊まちづくり』42:104-115.

大阪府立産業開発研究所, 2003, 『商業集積の活力についての調査報告書一アメリカ村、南船

場、堀江など新しい街の活力とは?』（産開研資料No.80）大阪府立産業開発研究所.

笹島秀晃, 2014,「SoHoにおける芸術家街の形成とジェントリフィケーション」『日本都市社会 学会年報』32:65-80.

佐々木雅幸，2012，『創造都市への挑戦——産業と文化の息づく街へ』（岩波現代文庫）岩波書店 Sassen, Saskia, 2001, The Global City: New York, London, Tokyo, 2nd edn. Princeton: Princeton University Press. (伊豫谷登士翁監訳 2008 『グローバル・シティ』筑摩書房)

佐藤(粒来)香, 2004, 『社会移動の歴史社会学』東洋館出版社.

佐藤芳雄編, 1981, 『巨大都市の零細工業——都市型末端産業の構造変化』日本経済評論社.

Soja, Edward, W., 2000, Postmetropolis: Critical Studies of Cities and Regions, Oxford: Basil Blackwell. 園部雅久, 2001, 『現代大都市社会論——分極化する都市?』東信堂

鈴木 淳, 2006,「台東デザイナーズビレッジオープンからの 2 年間を振り返って」『かわとは きもの』No.136 (2006.6)；8-13

鈴木 淳, 2011, 『「好き」を仕事にする自分ブランドのつくりかた』アスペクト

鈴木 淳・林きょうこ・藤井健雄, 2013, 「変貌を遂げる台東区、この街はいずれパリになる! 一クリエイターを惹きつけはじめた “東トーキョー、」『Biglife 21』2013年 5 月号 : 4149.

台東区文化産業観光部にぎわい計画課，2012，『台東区産業振興プラン—平成24 (2012) 年度〜 平成28 (2016) 年度』台東区役所.

台東区中小企業実態調査協議会編，1987，『台東区中小企業実態調査報告書［I］」台東区区民部 
商工課.

台東区産業部経営支援課，2004，「お役所仕事から一歩前へ(81) ファッション関連デザイナーの

創業支援施設 台東デザイナーズビレッジの開設」『地方自治職員研修』37 (8), 80-82.

台東モノマチ編集部, 2014, 『台東モノマチです!』第 1 号 台東モノづくりのマチづくり協会.

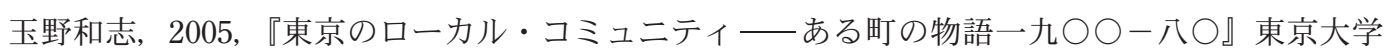
出版会.

植田浩史編著，2004，『「縮小」時代の産業集積』創風社.

渡辺幸男, 1997, 『日本機械工業の社会的分業構造一階層構造・産業集積からの下請制把握』 有斐閣.

山本俊一郎, 2008, 『大都市産地の地域優位性』ナカニシヤ出版.

有限会社浅原皮漉所，2013，「本当の職人の仕事を見せてやるつ」（特集 東京下町に見るモノづ くりの未来形 取材・加藤俊）『BigLife21』2013年 7 月号.

Zukin, Sharon, 2010, Naked City: The Death and Life of Authentic Urban Places, New York: Oxford University Press. (内田奈芳美・真野洋介訳 2013 『都市はなぜ魂を失ったか』講談社)

本研究は科学研究費補助金 (若手研究 (B) 24730437) に基づいて行つた。

(しもむら やすひろ/玉川大学リベラルアーツ学部准教授)

（原稿受付 2014 年 12 月 7 日 掲載決定 2015 年 5 月 6 日） 